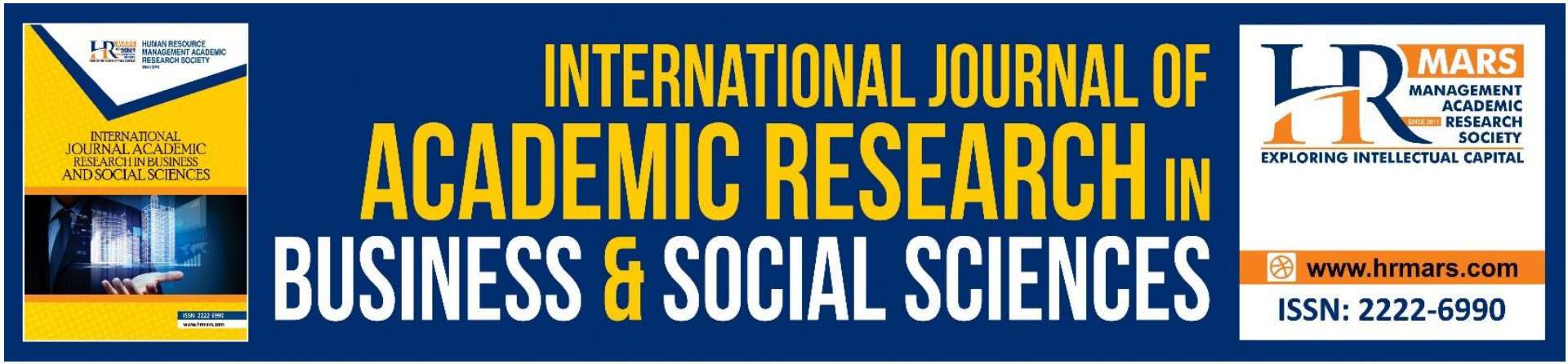

\title{
Co-operative Governance: A Systematic Review of Member Participation
}

\section{Mokhtaruddin Buang \& Asnarulkhadi Abu Samah}

To Link this Article: http://dx.doi.org/10.6007/IJARBSS/v11-i10/10997

DOI:10.6007/IJARBSS/v11-i10/10997

Received: 01 August 2021, Revised: 30 August 2021, Accepted: 18 September 2021

Published Online: 04 October 2021

In-Text Citation: (Buang \& Samah, 2021)

To Cite this Article: Buang, M., \& Samah, A. A. (2021). Co-operative Governance: A Systematic Review of Member Participation. International Journal of Academic Research in Business and Social Sciences, 11(10), 205-220.

\section{Copyright: @ 2021 The Author(s)}

Published by Human Resource Management Academic Research Society (www.hrmars.com)

This article is published under the Creative Commons Attribution (CC BY 4.0) license. Anyone may reproduce, distribute, translate and create derivative works of this article (for both commercial and non-commercial purposes), subject to full attribution to the original publication and authors. The full terms of this license may be seen at: http://creativecommons.org/licences/by/4.0/legalcode

Vol. 11, No. 10, 2021, Pg. 205 - 220

Full Terms \& Conditions of access and use can be found at http://hrmars.com/index.php/pages/detail/publication-ethics 


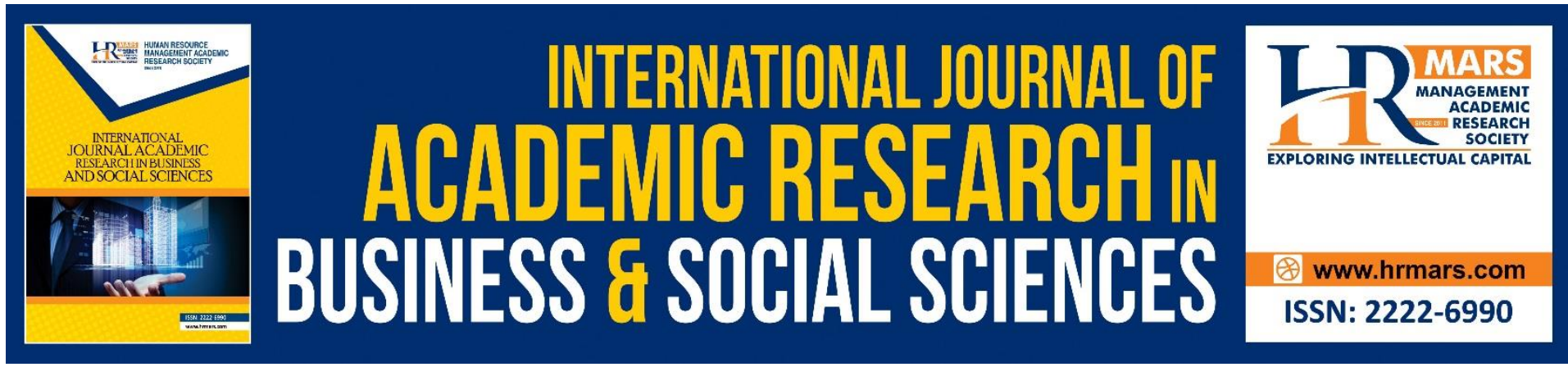

\title{
Co-operative Governance: A Systematic Review of Member Participation
}

\author{
Mokhtaruddin Buang ${ }^{1} \&$ Asnarulkhadi Abu Samah ${ }^{1,2}$ \\ ${ }^{1}$ Department of Social and Development Sciences, Faculty of Human Ecology, Universiti \\ Putra Malaysia, 43400 Serdang, Selangor, Malaysia, ${ }^{2}$ Institute for Social Sciences Studies, \\ Putra Infoport, Universiti Putra Malaysia, 43400 Seri Kembangan, Selangor, Malaysia
}

\begin{abstract}
Members' participation in co-operative governance is often seen as crucial to the organisation's operation and survival. However, there is still a dearth of a thorough knowledge of member participation and its aspects. Thus, this paper aims to synthesise the available research from the last ten years to enhance our knowledge of the patterns of the involvement of members in the governance of co-operative. Subsequently, the "Preferred Reporting Items for Systematic Reviews and Meta-Analyses" approach was used to perform a systematic review of the Scopus and Web of Science databases. We discovered 12 relevant peer-reviewed publications that match the objectives of this study with four themes of members' participation identified. In general, the findings revealed that the majority of the study has mainly focused on members' participation at annual general meetings, while participation via holding positions as board members remain limited. This paper makes a significant contribution by providing a review of the study on member participation in cooperative governance, as well as the patterns of member participation that have been studied using the systematic review method. Some recommendations for future research are given to explore other elements of member participation in strategic decision-making, particularly as the co-operative board.
\end{abstract}

Keywords: Co-operative, Members, Participation, Governance, Systematic Review

\section{Introduction}

Co-operatives are significant commercial organisations in many areas of the globe (Grashuis $\& Y e, 2019)$, and their viability is contingent on the degree to which members participate in co-operative governance ('Aini, Hafizah, \& Zuraini, 2012; Amini \& Ramezani, 2008; Sushila Devi Rajaratnam, Noordin, Said, Juhan, \& Hanif, 2010). Previous research has shown that there are two distinct forms of participation in the co-operative's governance: one is via involvement in the general assembly, and the other is by holding a seat on a board or committee (Barraud-Didier, Henninger, \& El Akremi, 2012; Bijman, Hanisch, \& van der Sangen, 2014; Birchall \& Simmons, 2004; Cechin et al., 2020; Liang et al., 2015).

A general assembly, which typically occurs once a year, is a gathering of the cooperative's members to address strategic problems (Hakelius \& Nilsson, 2020). The "one 
member, one vote" principle (Liang et al., 2015), which co-operatives often use, is a critical component of the democratic character of co-operative decision-making (Cechin et al., 2013). In addition to attending the annual meeting, according to Barraud-Didier et al., 2012), member may increase its involvement in co-operative's governance by serving as the board members. Such diagonal degree of engagement (Pozzobon \& Zylbersztajn, 2013) allows a member to have a direct impact on the co-operative's strategy, policies, and activities (Cechin et al., 2013) that contribute to co-operative performance.

Following that, Birchall and Simmons (2004) proposed categorising member participation based on (1) who are prospective members of the board ('believers') (2) who attended the annual meeting ('supporters') and (3) non-participating members, who are pleased if they are provided with information. Cechin et al (2013) proposed four typologies of member involvement in the co-operative's governance, guided from Birchall and Simmons' (2004) typologies, which combine both frequencies of involvement in the annual meeting and occupying the boardroom, namely (1) "Passive" refers to someone that has just an economic connection with the co-operative; (2) "Occasional supporter", who will occasionally participate in the general assembly; (3) "Involved", who will actively participate in the general assembly; and (4) "Pro-active", who will occupy positions at the board level.

Since member involvement in co-operative internal decision-making processes through general assembly and board membership is critical, this paper will synthesise empirical work done over the last decade in accordance with the member participation typologies proposed by Cechin et al (2013) to evaluate the aspects that have been investigated. As a consequence, this study allows us to consolidate and categorise the relevant publications based on the proposed typologies in order to examine the pattern of prior research, allowing us to investigate additional possible perspectives on member involvement in the co-operative's governance

\section{Methodology}

Derived from previous literature and debates, the reason for doing this research is based on the assumption that there is insufficient attention and literature on co-operative governance (Intan Waheedah Othman, Maslinawati Mohamad, \& Abdullah Azizah, 2013). Thus, this review enables us to consolidate and classify pertinent publications based on patterns of member participation, as their involvement in co-operative governance is critical to the organisation's sustainability (Berge, Caldwell \& Mount, 2016).

According to Moher, Liberati, Tetzlaff, and Altman (2010), a systematic review is a study of a defined problem that use structured and clear techniques to find, identify, and systematically assess related studies by collecting as well as analysing findings in previous research. Authors' claims of accuracy in their work by using this approach, allowing for the identification of gaps and recommendations for further research (Shaffril, Krauss \& Samsuddin, 2018). This systematic review will include information on the review methods employed, as well as an overview of the aspects related to the studies of the members' participation, all of which may help future researchers concentrate on research that is relevant to their interests and concerns. In creating a comprehensive systematic review, this paper was motivated by two main research questions: (1) What can be gleaned from recent publications and empirical studies over the last 10 years to aid in identifying the pattern of 
member participation? (2) What dimensions of member's participation in the governance of co-operative have been discussed?

The systematic review was carried out using "Preferred Reporting Items for Systematic Reviews and Meta-Analyses" (PRISMA) methodology proposed by Moher et al.(2010), which comprises specific criteria, reviewing procedure stages (classification, filtering, and eligibility), data abstraction, as well as analysis. Although this technique is commonly used in the medical and healthcare sectors, Moher et al. (2010) suggest that since it is based on a structured inquiry, it may also be used to report systematic reviews in other types of research disciplines. It searches, selects, and evaluates the articles in the review using structured and clear procedures. (Higgins \& Green, 2006). Hence, PRISMA allows for a comprehensive search for keywords relevant to member participation in co-operative governance.

\section{Resources}

This study's review method makes use of two major journal databases, Web of Science and Scopus (WoS). Scopus is the world's most comprehensive abstracts and reference repository of publications, with 22,800 journals from over 5,000 publishers with a broad variety of subjects covering economics, art and humanities and social science. WoS, on the other hand, is used in this study since it is a comprehensive database that contains 18,000 high-impact journals from 3,300 publishing partners, as well as over 5,200 articles on social science covering 55 disciplines, including topics like economics, business, and management. Furthermore, it has almost 100 years of completely indexed data, including records and back files rated by citations, publications, and citations per paper.

\section{Eligibility and Exclusion Criteria}

Some inclusion and exclusion criteria have been established. To begin, in terms of document type, only article journals are chosen, excluding conference proceedings, chapters in books, book series, books, and review articles. Second, to prevent any misunderstanding or difficulty in translation, the search attempts were limited to papers published in English. Third, only studies published between 2012 and 2021 (ten years) are chosen to examine the evolution of research and relevant publications, since more than 5 years is an adequate duration for systematic review updates (Bashir, Surian \& Dunn, 2018). Finally, in accordance with its goal, which focuses on member involvement in co-operative governance, publications indexed exclusively in social science-based databases are chosen. As a result, publications listed in the science citation index are not included.

\section{Systematic Review Process}

The systematic review procedure of the research (refer Figure 1), which was performed in August 2021, consisted of four steps. The initial step was to determine the keywords that will be utilised in the search process. Keywords relating to co-operative, member, participation, and governance were employed based on prior research and a thesaurus. The author used the terms "cooperatives," "co-operative," "co-ops," "participation," "involvement," "engagement," "member," "governance," and "administration" to search the database. To identify variants in the terms, an asterisk $(*)$ was added to the keywords (Table 1). 41 duplicated articles were removed after a comprehensive review. These duplications are caused by similarities in the journals that appeared in both databases in different fields. 
Table 1: The systematic review search string

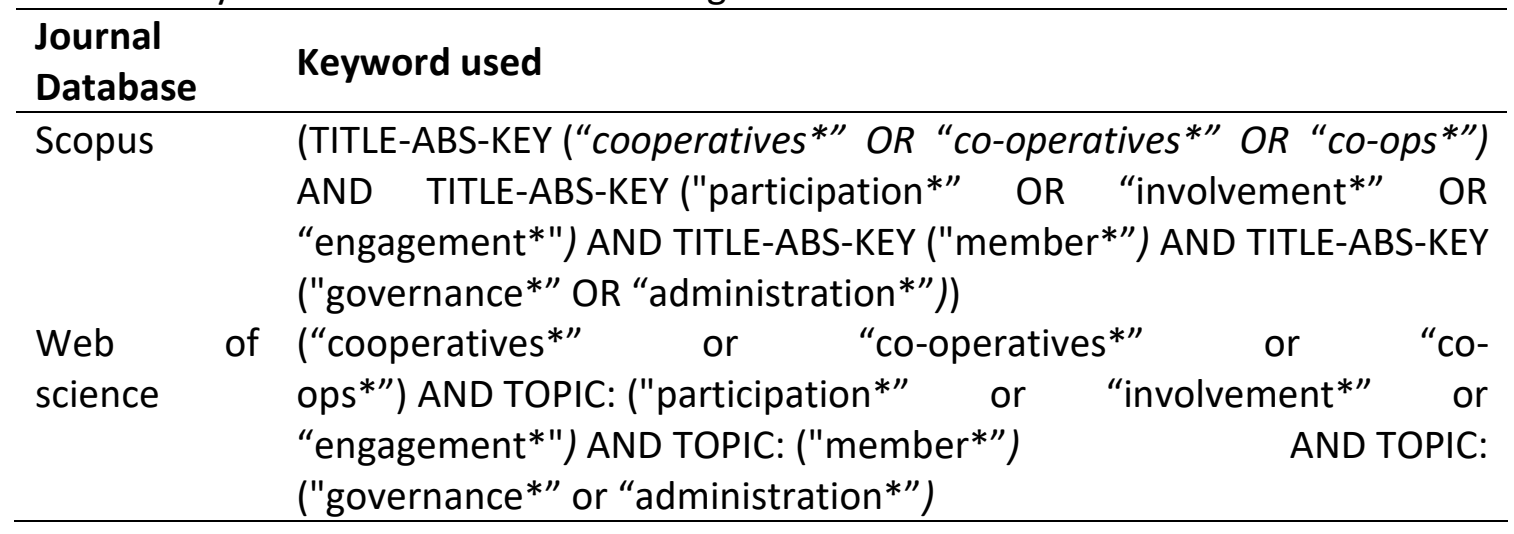

The second step included screening the articles based on the specified inclusion and exclusion criteria, which resulted in the elimination of 26 of the 152 items. The next step is to review the titles and abstracts to verify that they are relevant to the study's objectives. At this point, 114 articles had been deleted because of their unsuitable content in terms of member participation in co-operative governance. The last screening process resulted in a total of 12 articles for qualitative analysis. 


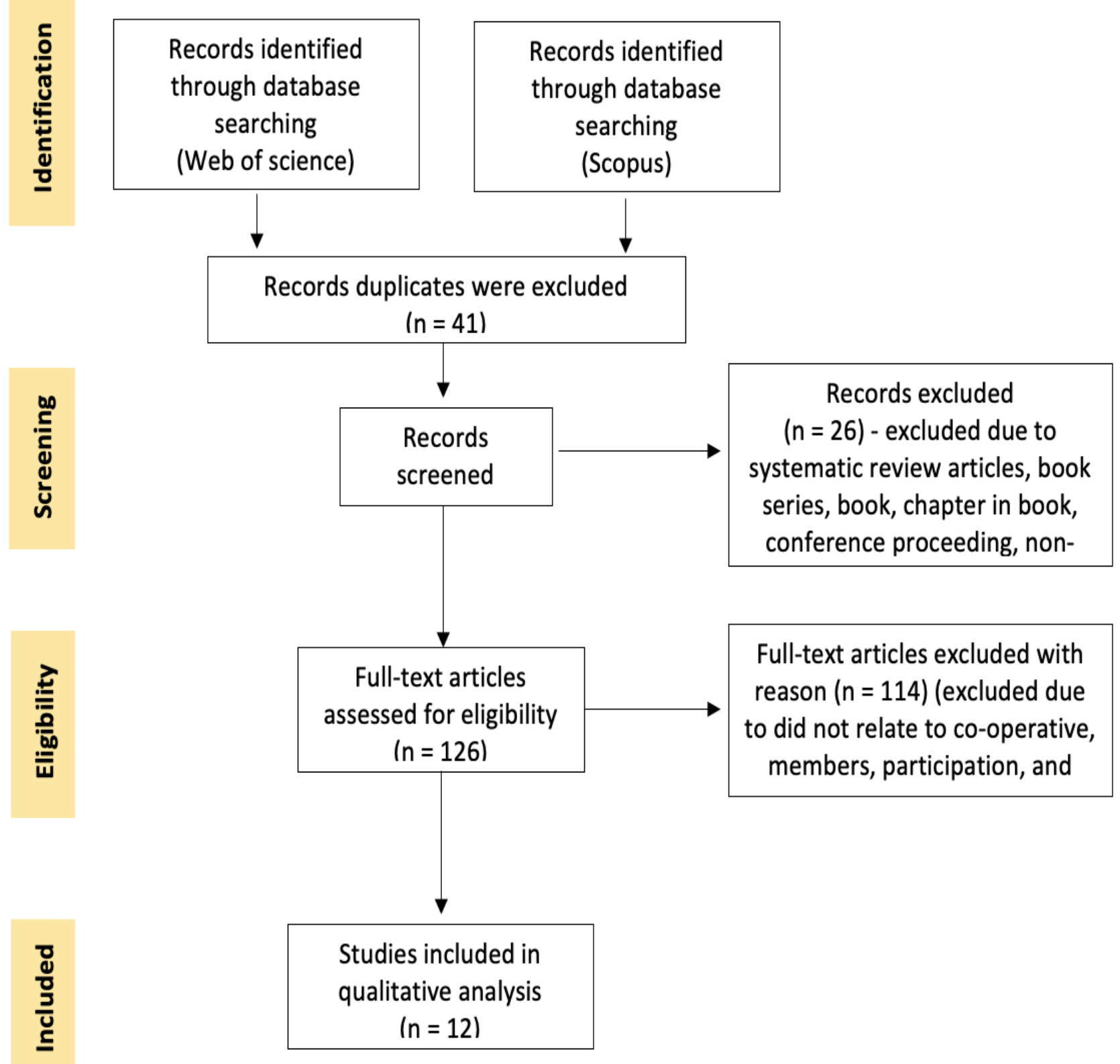

Figure 1: Systematic review process (adopted from Moher et al., 2010)

\section{Data Abstraction and Analysis}

The 12 articles were evaluated and analysed, with a concentration on particular studies that addressed the formulated questions. The information was gathered by first reading the abstracts and then proceeding to the full articles. As indicated in Table 2, the publications were then classified according to the authors, country, title, objective, main study design, sample, and key findings. Following that, a qualitative research was conducted, and content analysis was used to identify the pertinent themes based on Cechin et al.'s (2013) typologies of member involvement in co-operative governance. 
Table 2: Overview of Empirical Literature on Co-operative Members' Participation

\section{Author(s) / Country Main StudySample Key Finding(s)}

Design

1. Morfi, Nilsson,QN

Hakelius, $\&$

Karantininis (2021) /

Sweden

2. Hakelius \& NilssonQL (2020) / Sweden

3. Mwambi, Bijman,QN \& Mshenga (2020) / Kenya

4. García Lozano,QL Smith, \& Basurto (2019) / Mexico

5. Kleanthous, Paton, QL \& Wilson (2019) /

Cyprus

6. Boone \& ÖzcanQN (2016) / Belgium
2,210 members of Swedish Farmers' willingness to agricultural co-operatives participate in co-operative in 1993, 2003, and 2013 governance is strongly influenced by their social networks

Case study of two largest Co-operative ownership Swedish agricultural co- based on equity capital has operatives, namely increased member Lantmännen and Södra participation in governance, Skogsägarna particularly in large cooperatives

595 members of dairy Members who are older, farmer co-operative male, and specialize in farming are more likely to participate in decisionmaking

Observation of the 2016 CONMECOOP's general assembly of CONMECOOP assembly acts as a political arena for open democratic participation among members, demonstrating how the views on issues like as climate change are addressed

Case study of nine credit The results indicate that low unions member participation weakens governance and that co-operative principles are no longer consistently implemented by credit unions in Cyprus

388 plants (of which 86 co- The bio-ethanol business in operatives) the United States demonstrates that cooperatives outlast corporations provided the initial investment (equity shares) is substantial 
7. Berge, Caldwell, \&QL Mount (2016) /

Canada

8. Liang, Hendrikse,QN Huang, \& Xu (2015) /

China

9. Verhees, Sergaki,QN

\& Van Dijk (2015) /

Netherlands

10. Cechin, Bijman,QN

Pascussi,

Zybersztajn, \& Omta

(2013) / Brazil

11. Pozzobon \&QL Zylbersztajn (2013) /

Brazil

12. Barraud-Didier,QN

Henninger, \& El

Akremi (2012) /

France
Semi-structured interview The research discovered

- 9 managers

that the board's function varies according to the cooperative's life cycle, which influences their degree of participation in co-operative governance

37 fruit and vegetable co- The results indicate that in operatives 34 of 37 co-operatives, core members had a greater influence in decision-making than common members

241 members of a Dutch Active participation in the feed supply co-operative general meeting is based on social factors such as cooperative culture, open communication, trust, and a willingness to participate

148 farmers from According to the findings, agricultural co-operative economic incentives for continuing membership motivate participation in the General Assembly but not in of 'pro-active' participation in boards and committees

Semi structured The findings revealed that interviews - Managers the degree of member from 12 agricultural co- participation in the general operatives assembly and as the board members had a direct impact on democratic expenses

259 farmer-members from Members' participation in French agricultural co- the annual general meeting operatives of French agricultural cooperatives is affected by their trust in the directors and emotional attachment to their co-operative

Notes: QN: Quantitative; QL: Qualitative 


\section{Result and Discussion}

Addressing the first aim of this study, based on the findings of the systematic review process, the researcher identified 12 empirical studies conducted over a 10-year period to aid in identifying the pattern of member participation, as indicated in Table 2. ('tracked changes')

Two studies explored at member involvement in Asian countries, while six looked at it in European countries including Portugal, Belgium, the Netherlands, France, and Sweden. Meanwhile, four studies were conducted in the Americas, specifically in Mexico, Canada, and Brazil, while only one study was conducted in Africa, particularly in Kenya. In addition, seven studies used quantitative methods, while the remaining five used qualitative analytical methods. In terms of publication years, two studies were published in 2013, 2015, 2016, 2019 and 2020, and one study was conducted in each of the following years: 2012 and 2021. Meanwhile in 2014, 2017 and 2018, there was no publication (Figure 2). According to the findings, studies on member participation in co-operative governance are still inadequate.

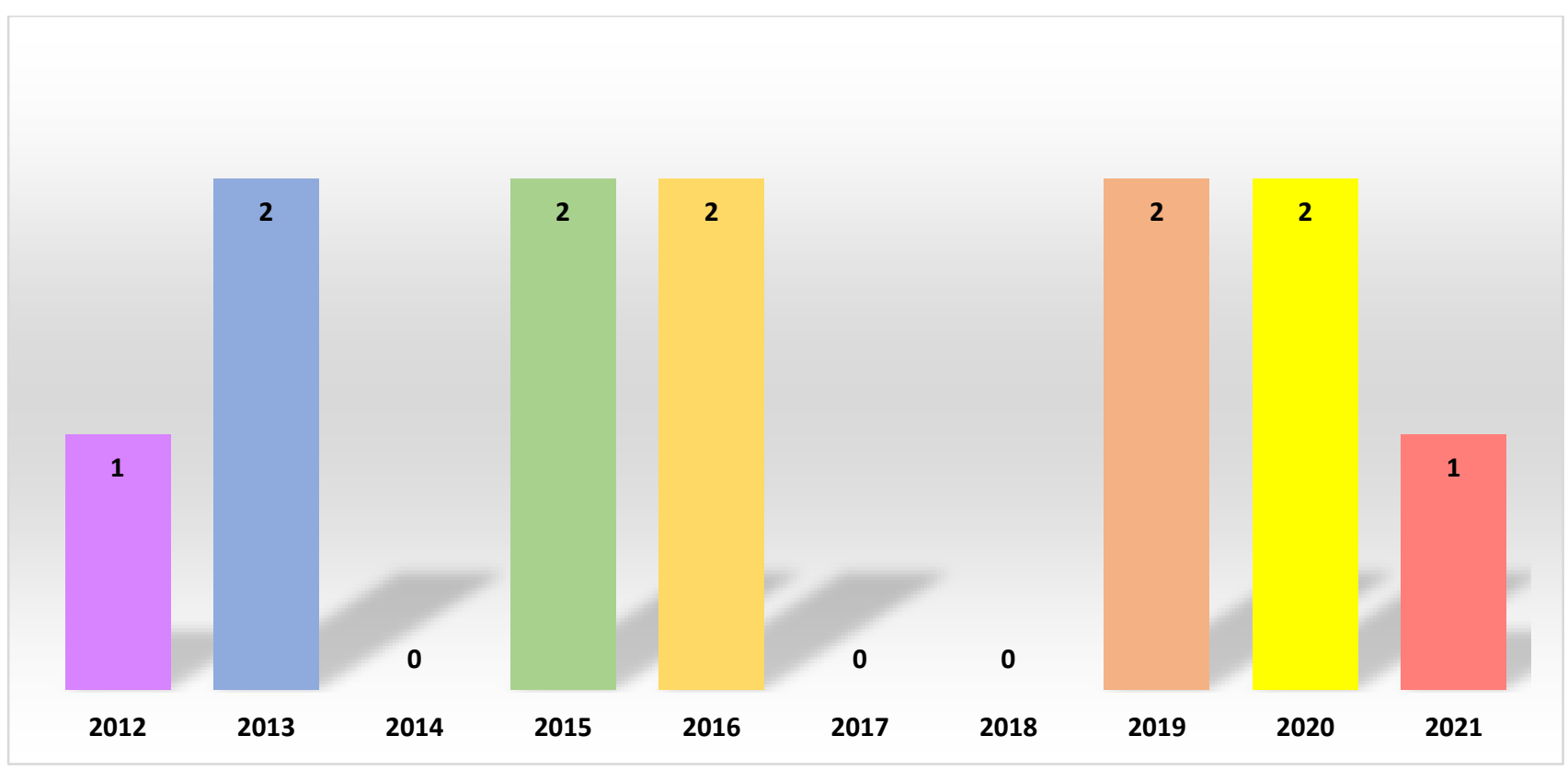

Figure 2: Number of articles published by year

In response to the study's second objective of identifying the dimensions of member participation in co-operative governance, which will be discussed in detail in the following subsection, the study revealed four main themes concerning members' engagement in cooperative governance, namely "Passive," "Occasional supporter," "Involved," and "Proactive," as shown in Table 3. ('tracked changes')

\section{Patterns of Member Participation}

This section focuses on the patterns of member participation in co-operative governance as a "Passive," "Occasional supporter," "Involved," and "Pro-active." Table 3 summarizes the findings of the reviewed studies based on the themes stated. 
Table 3: Summary of Reviewed Studies

\begin{tabular}{l} 
Author(s)/Country Pass \\
\hline 1. Morfi, Nilsson, Hakelius, \& \\
Karantininis (2021)/Sweden \\
$\begin{array}{l}\text { 2. Hakelius \& Nilsson (2020) / } \sqrt{ } \\
\text { Sweden }\end{array}$
\end{tabular}

3. Mwambi, Bijman, \& Mshenga (2020) / Kenya

4. García Lozano, Smith, \& Basurto (2019) / Mexico

5. Kleanthous, Paton, \& Wilson (2019) / Cyprus

6. Boone \& Özcan (2016) / Belgium $\sqrt{ }$

7. Berge, Caldwell, \& Mount (2016) /

Canada

8. Liang, Hendrikse, Huang, \& Xu (2015) / China

9. Verhees, Sergaki, \& Van Dijk (2015) / Netherlands

10. Cechin, Bijman, Pascussi, Zybersztajn, \& Omta (2013) / Brazil

11. Pozzobon \& Zylbersztajn (2013) / Brazil

12. Barraud-Didier, Henninger, \& El Akremi (2012) / France

\section{"Passive"}

The member's "passive" participation is considered the lowest level of member participation, in which according to Cechin et al. (2013) their participation is simply an economic connection with the co-operative and they are not keen in becoming engage in decision-making. Resulted of the review procedure, two of the twelve studies (Boone \& Özcan, 2016; Hakelius \& Nilsson, 2020) were discovered to be discussing the passive participation of the members. In their study, Boone and Özcan (2016) found that the initial monetary involvement at founding would encourage commitment of the members to contribute to the co-operative's effective daily operations, and this is especially true when the initial contributed money is substantial. Nonetheless, as the co-operative approached maturity, which is typical of a large cooperative, Hakelius and Nilsson (2020) discovered that members were not actively involved 
in co-operative governance. In this scenario, members' passivity in co-operative governance is explained as a result of their satisfaction and trust in their elected representatives. According to Wood (1992), this scenario is referred to as the corporate phase, in which management assumes increased responsibilities as the co-operative's manager.

\section{"Occasional Supporter"}

Based on the results as shown in Table 3, it highlighted that only one study focused on members' participation in co-operative governance as a "Occasional Supporter," who sometimes involves in the voting process in the general assembly. Kleanthous et al. (2019) found that members only participated if they were clients of the co-operative in their case study of a credit union in Cyprus. Aside from that, they discovered that members who attend general meetings is to involve in the board of directors' selection. One possible explanation for this pattern of participation is that credit unions did not engage members in terms of education or training. This finding is consistent with Cechin et al.'s (2013) inference that the lower a member's level of education, the more likely he or she would be an occasional supporter.

\section{"Involved"}

The findings of this study also discovered that a total of seven studies examined the active involvement of members in the democratic decision making which illustrated through voting in general assemble (Barraud-Didier et al., 2012; Cechin et al., 2013; García Lozano et al., 2019; Liang et al., 2015; Mwambi et al., 2020; Pozzobon \& Zylbersztajn, 2013; Verhees et al., 2015). Speaking up is one of the aspects of members' active involvement in the annual general meeting that has been investigated (Barraud-Didier et al., 2012; Mwambi et al., 2020). Mwambi et al. (2020) discovered, based on an data of 595 smallholder dairy farmers cooperatives in Kenya, that members' desire to speak up at the annual general meeting is impacted by their trust in the co-operative represented by the board members, which is supported by Barraud-Didier et al. (2012). In addition, García Lozano et al. (2019) observed that in Mexico, the general assembly acts as a special foundation for open democratic engagement between members and government actors, as well as the members' avenues (Barraud-Didier et al., 2012) to voice concerns related to fisheries issues, resulting in active participation by the members.

Since voting at the general assembly is an essential part of a co-operative's democratic decision-making process, most co-ops have embraced the "one-member-one-vote" principle (Barraud-Didier et al., 2012; Berge et al., 2016; Cechin et al., 2013; Liang et al., 2015). Likewise, as stated in the Chinese Farmer Cooperative Law, a similar principle is applied in farmer cooperatives in China, where, according to a study conducted by Liang et al. (2015), the majority of members voting are among the co-operative's core members who are the owners and in charge of its management. Meanwhile, Cechin et al. (2013) highlighted that the higher pricing for farm goods, and technical support are the motivating elements for ongoing connection with the co-operative that will improve the probability of being an active member in the agricultural co-operative.

Furthermore, Verhees et al. (2015) in their research involving 2316 members of a Dutch agricultural co-operative found that members' active involvement promotes the establishment of a democratic social framework that enables collective decision-making and 
collective action execution. Nevertheless, using data from 12 Brazilian agricultural cooperatives, Pozzobon and Zylbersztajn (2013) put forth that co-operatives with a greater degree of member involvement in the general assembly spend more resources on the process of collective decision-making, resulting in higher direct democratic costs.

\section{"Pro-active"}

Meanwhile, based on the results shown in Table 3, five studies addressed the "Pro-Active" involvement of members who hold positions as board members (Berge et al., 2016; Cechin et al., 2013; Morfi et al., 2021; Mwambi et al., 2020; Pozzobon \& Zylbersztajn, 2013). In their latest study of identifying members' social networks and their desire to participate in the governance of co-operative, Morfi et al. (2021) discovered that the farmers' personal networks influence their propensity to occupy the board position through bridging and bonding social capital (Putnam, 2000).

Furthermore, in order to be effective while sitting on the board, Mwambi et al. (2020) recommended that very young farmers not be elected since they have not yet built up social capital, which is supported by Cechin et al. (2013), who found that the duration of membership is an important driver of pro-active participation, which involves those of older farmers. Apart from that, Mwambi et al. (2020) also discovered that farmers with significant farm assets benefit more from sitting on the board in order to improve their economic position (Lutz \& Tadesse, 2017).

Meanwhile, based on co-operative's life cycle proposed by Wood (1992), Berge et al. (2016) highlighted the important role played by the board, particularly in the "Supermanaging phase" where the co-operative has been in operation for more than five years and has a larger membership base than the newer co-operative that has been in operation for less than a year.

Besides that, Cechin et al. (2013), who studied 148 farmers from a large agricultural co-operative in Brazil observed that co-operative ideology appears to be a more significant driver of pro-active engagement. According to Fulton (1999), co-operative ideology is the basis of farmers' commitment to the co-operative, especially based on co-operative values such as democratic member control and concern for the community. However, Pozzobon and Zylbersztajn (2013) claimed that expanding boardroom involvement raises direct democratic costs at the board level, especially when board size becomes extremely large.

To summarise, as mentioned, this study produces four main themes addressing members' participation in cooperative governance, ranging from "passive" to "pro-active." Based on the above-mentioned literature study, Figure 3 displayed the members' characteristics as well as their degree of participation. 


\begin{tabular}{|c|c|c|}
\hline Degree & Level & Characteristic \\
\hline \multirow[t]{3}{*}{ High } & "Pro-active" & $\begin{array}{l}\text { - Occupy positions as board members } \\
\text { - Members have personal networking with others } \\
\text { - Maturity of the co-operative's members } \\
\text { - Possess substantial assets }\end{array}$ \\
\hline & "Involved" & $\begin{array}{l}\text { - Always vote in the general assembly } \\
\text { - Members are likely to speak up and express their } \\
\text { views during the general assembly. } \\
\text { - Participated in collective decision-making and } \\
\text { action }\end{array}$ \\
\hline & $\begin{array}{l}\text { "Occasional } \\
\text { Supporter" }\end{array}$ & $\begin{array}{l}\text { - Participates in the voting process in the general } \\
\text { assembly on occasion } \\
\text { - Members with a lower level of education }\end{array}$ \\
\hline$\downarrow$ & "Passive" & $\begin{array}{l}\text { - Involvement in monetary terms at the start-up } \\
\text { - Not interested in getting involved in decision- } \\
\text { making }\end{array}$ \\
\hline Low & & $\begin{array}{l}\text { - Not actively participating in co-operative } \\
\text { governance }\end{array}$ \\
\hline
\end{tabular}

Figure 3: Members' Characteristics and Degree of Participation in Co-operative Governance

\section{Conclusion}

This systematic analysis highlighted prior works and empirical research published in the past 10 years, as well as an attempt to identify the dimensions in evaluating members' participation in co-operative governance. Following an assessment of the aforementioned literature, the overall results revealed that the investigations are still inadequate, as shown in Figure 2. Hence, given the scarcity of such studies at the moment, this opens up a new avenue for an empirical study on member involvement in co-operative governance.

Within the period range of the evaluations, previous scholars suggested different aspects of member involvement in co-operative governance. The authors categorised members' engagement in co-operative governance into four categories: "Passive", "Occasional supporter", "Involved", and "Pro-active". As shown in Table 3, the majority of the study (seven studies) concentrated on assessing members' active involvement in voting at the general assembly meeting. Nevertheless, the participation of members in the boardroom, which is thought to have an impact on the co-operative's performance, has only been investigated by five studies, and the discussion has not explored the behaviour of board members' participation, especially in the strategic decision-making process, which has the potential to be explored in depth.

According to Fiegener (2005), it is significant to investigate board participation behaviour in the strategic decision-making process, which has an indirect impact on firm performance (Judge \& Zeithaml, 1992). The board involvement in the strategic decisionmaking process, which includes establishing strategic objectives, developing strategic alternatives, assessing strategic options, executing the strategy, and monitoring and evaluating strategy implementation, has been studied previously in the context of corporate governance. (e.g., Fama \& Jensen, 1983; Judge \& Zeithaml, 1992; Lynch, 1979; Siciliano, 2005; 
Zahra \& Pearce, 1990). Likewise, in a co-operative governance setting, the board members are in charge of monitoring operational effectiveness, creating long-term strategic goals, evaluating management suggestions, and understanding the organization's financial and strategic activities (Hakelius, 2018; Bond, 2009). Moreover, since co-operatives are systematically governed by democratic control (Shamsuddin, Mahmood, Liza Ghazali, Salleh, \& Amalina Md Nawi, 2018), the board members are responsible for conducting and implementing effective governance on the basis of the policies and guidelines approved at the annual general meeting (Abd Kadir et al., 2016). Therefore, their active involvement in cooperative administration as Chairman, Secretary, Treasurer, and Board Members is critical as a monitoring tool for co-operative administrative and day-to-day operations (Abd Kadir et al., 2016).

Therefore, to leverage on the results of this study, future research should concentrate on co-operative board members' participation behaviour in strategic activities, since this has yet to be explored. Examining this element will offer new insights into co-operative settings, particularly on members' involvement in the boardroom.

\section{Reference}

'Aini, Y. M., Hafizah, H. A. K., \& Zuraini, Y. (2012). Factors affecting cooperatives' performance in relation to strategic planning and members' participation. Procedia - Social and Behavioral Sciences, 65, 100-105.

Amini, A. M., \& Ramezani, M. (2008). Investigating the success factors of poultry growers' cooperatives in Iran's western provinces. World Applied Sciences Journal, 5(1), 81-87.

Barraud-Didier, V., Henninger, M.-C., \& El Akremi, A. (2012). The relationship between members' trust and participation in the governance of cooperatives: The role of organizational commitment. International Food and Agribusiness Management Review, 15(1), 1-24. R

Bashir, R., Surian, D., \& Dunn, A. G. (2018). Time-to-update of systematic reviews relative to the availability of new evidence. Systematic Reviews, 7(1), 195.

Berge, S., Caldwell, W., \& Mount, P. (2016). Governance of nine Ontario food co-operatives. Annals of Public and Cooperative Economics, 87(3), 457-474.

Bijman, J., Hanisch, M., \& van der Sangen, G. (2014). Shifting control? The changes of internal governance in agricultural cooperatives in the EU. Annals of Public and Cooperative Economics, 85(4), 641-661.

Birchall, J., \& Simmons, R. (2004). The involvement of members in the governance of largescale co-operative and mutual businesses: A formative evaluation of the co-operative group. Review of Social Economy, 62(4), 487-515.

Boone, C., \& Özcan, S. (2016). Strategic choices at entry and relative survival advantage of cooperatives versus corporations in the US bio-ethanol industry, 1978-2015. Journal of Management Studies, 53(7), 1113-1140.

Cechin, A., Bijman, J., Pascussi, S., Zybersztajn, D., \& Omta, O. (2013). Drivers of pro-actives member participation in agricultural cooperatives: Evidence from Brazil. Annals of Public and Cooperative Economics, 84(4), 443-468.

Fama, E. F., \& Jensen, M. C. (1983). Agency problem and residual claims. Journal of Law and Economics, 26(2), 1-29.

Fiegener, M. K. (2005). Determinants of board participation in the strategic decisions of small corporations. Entrepreneurship: Theory and Practice, 29(5), 627-650. 
Fulton, M. (1999). Cooperatives and Member Commitment. The Finnish Journal of Business Economics, 4.

Grashuis, J., \& Ye, S. U. (2019). A review of the empirical literature on farmer cooperatives: performance, ownership and governance, finance, and member attitude. Annals of Public and Cooperative Economics, 90(1), 77-102.

Hakelius, K. (2018). Understanding the board of Swedish farmer cooperatives - Cases focusing on board composition and interaction patterns. Journal of Co-operative Organization and Management, 6(2), 45-52.

Hakelius, K., \& Nilsson, J. (2020). The logic behind the internal governance of Sweden's largest agricultural cooperatives. Sustainability (Switzerland), 12(21), 1-19.

Higgins, J., \& Green, S. (2006). Cochrane Handbook for Systematic Reviews of Interventions. The Cochrane Library.

Judge, W. Q., \& Zeithaml, C. P. (1992). Institutional and strategic choice perspectives on board involvement in the strategic decision process. Academy of Management Journal. Academy of Management.

Bond, K. J. (2009). Cooperative financial performance and board of director characteristics: A quantitative investigation. Journal of Cooperatives, 22, 20-35.

Kleanthous, A., Paton, R. A., \& Wilson, F. M. (2019). Credit unions, co-operatives, sustainability and accountability in a time of change: A case study of credit unions in Cyprus. International Journal of Social Economics.

Liang, Q., Hendrikse, G., Huang, Z., \& Xu, X. (2015). Governance structure of chinese farmer cooperatives: Evidence from Zhejiang Province. Agribusiness, 31(2), 198-214.

Lutz, C., \& Tadesse, G. (2017). African farmers' market organizations and global value chains: competitiveness versus inclusiveness. Review of Social Economy, 75(3), 318-338.

Lynch, J. M. (1979). Activating the board of directors: A study of the process of increasing board effectiveness. Harvard University.

Moher, D., Liberati, A., Tetzlaff, J., \& Altman, D. G. (2010). Preferred reporting items for systematic reviews and meta-analyses: The PRISMA statement. International Journal of Surgery, 8(5), 336-341.

Morfi, C., Nilsson, J., Hakelius, K., \& Karantininis, K. (2021). Social networks and member participation in cooperative governance. Agribusiness, 37(2), 264-285.

Mwambi, M., Bijman, J., \& Mshenga, P. (2020). Which type of producer organization is (more) inclusive? Dynamics of farmers' membership and participation in the decision-making process. Annals of Public and Cooperative Economics, 91(2), 213-236.

Pozzobon, D. M., \& Zylbersztajn, D. (2013). Democratic costs in member-controlled organizations. Agribusiness, 29(1), 112-132.

Putnam, R. D. (2000). Bowling Alone: The Collapse and Revival of American Community. New York: Simon and Schuster.

Rebelo, J. F., Leal, C. T., \& Teixeira, Â. (2017). Management and financial performance of agricultural cooperatives: A case of Portuguese olive oil cooperatives. REVESCO Revista de Estudios Cooperativos, 123, 225-249.

Shamsuddin, Z., Mahmood, S., Ghazali, L. P., Salleh, F., \& Nawi, A. M. F. (2018). Indicators for Cooperative Performance Measurement. International Journal of Academic Research in Business and Social Sciences, 8(12), 577-585.

Siciliano, J. I. (2005). Board involvement in strategy and organisational performance. Journal of General Management, 30(4), 1-10.

Rajaratnam, S. D., Noordin, N., Said, M. S. A., Juhan, R., \& Hanif, F. M. (2010). Success factors 
of cooperatives in Malaysia: An exploratory investigation. Malaysian Journal of CoOperative Management, 5(1), 1-24.

Verhees, F. J. H. M., Sergaki, P., \& Van Dijk, G. (2015). Building up active membership in cooperatives. New Medit, 14(1), 42-52.

Wood, M. M. (1992). Is governing board behavior cyclical? Nonprofit Management and Leadership, 3(2), 139-163.

Zahra, S. A., \& Pearce, J. A. (1990). Determinants of board directors' strategic involvement. European Management Journal, 8(2), 164-173. 